\title{
Inhibition of Cocaine and 3,4-Methylenedioxypyrovalerone (MDPV) Self-Administration by Lorcaserin Is Mediated by 5-HT2C Receptors in Rats
}

\author{
Brenda M. Gannon, Agnieszka Sulima, Kenner C. Rice, and Gregory T. Collins \\ Department of Pharmacology, University of Texas Health Science Center at San Antonio, San Antonio, Texas (B.M.G., G.T.C.); \\ South Texas Veterans Health Care System, San Antonio, Texas (G.T.C.); and Drug Design and Synthesis Section, Molecular \\ Targets and Medications Discovery Branch, National Institute on Drug Abuse and National Institute on Alcohol Abuse and \\ Alcoholism, Bethesda, Maryland (A.S., K.C.R.)
}

Received October 31, 2017; accepted November 30, 2017

\begin{abstract}
Lorcaserin is a serotonin $(5-\mathrm{HT})_{2 \mathrm{C}}$ receptor-preferring agonist approved by the US Food and Drug Administration to treat obesity. Lorcaserin decreases cocaine self-administration in rats and monkeys. Although this effect is partially inhibited by a $5-\mathrm{HT}_{2 \mathrm{C}}$ receptor antagonist (SB242084), lorcaserin also has effects at $5-\mathrm{HT}_{2 \mathrm{~A}}$ and $5-\mathrm{HT}_{1 \mathrm{~A}}$ receptors, and the relative contribution of these receptors to its anti-cocaine effects has not been investigated. The goals of this study were to determine 1) the potency and effectiveness of lorcaserin to decrease self-administration of cocaine and 3,4-methylenedioxypyrovalerone (MDPV), a common "bath salts" constituent; and 2) the receptor(s) mediating the effects of lorcaserin on cocaine and MDPV self-administration. Male Sprague-Dawley rats $(n=6)$ were trained to self-administer MDPV under a progressive ratio schedule of reinforcement and maintained
\end{abstract}

under this schedule with daily access to $0.32 \mathrm{mg} / \mathrm{kg}$ per infusion of cocaine or $0.032 \mathrm{mg} / \mathrm{kg}$ per infusion of MDPV. Dose-response curves for the effects of lorcaserin on cocaine and MDPV selfadministration were generated by administering lorcaserin $(0.1-5.6 \mathrm{mg} / \mathrm{kg}) 25$ minutes before the start of the session. To assess the effects of $5-\mathrm{HT}_{2 \mathrm{C}}$ (SB242084, $0.1 \mathrm{mg} / \mathrm{kg}$ ), $5-\mathrm{HT}_{2 \mathrm{~A}}$ (MDL100907, $0.1 \mathrm{mg} / \mathrm{kg}$ ), and 5-HT AA WAY100635, $0.178 \mathrm{mg} / \mathrm{kg}$ ) receptor antagonists, they were administered 15 minutes before lorcaserin. Lorcaserin decreased cocaine and MDPV selfadministration with equal potency. Antagonism of $5-\mathrm{HT}_{2 \mathrm{C}}$ (but not $5-\mathrm{HT}_{1 \mathrm{~A}}$ or $5-\mathrm{HT}_{2 \mathrm{~A}}$ ) receptors blocked the effects of lorcaserin on cocaine and MDPV self-administration. Taken together, these data provide additional support for further development of $5-\mathrm{HT}_{2 \mathrm{C}}$ receptor agonists, such as lorcaserin, for the treatment of stimulant abuse.

\section{Introduction}

Globally, stimulants (e.g., amphetamines, cocaine, synthetic cathinones) are one of the most widely used classes of drugs (United Nations Office on Drugs and Crime, 2016). Although these drugs interact with dopamine (DAT), serotonin, and norepinephrine transporters to inhibit monoamine uptake (i.e., cocaine-like monoamine uptake inhibitor) or stimulate release (i.e., amphetamine-like monoamine transporter substrate), the abuse-related effects of stimulants are mediated primarily by their capacity to enhance dopaminergic neurotransmission (e.g., Ritz et al., 1987; Gannon et al., $2017 \mathrm{~b})$. Because of this central role for dopamine in reward and reinforcement, efforts to develop medications to treat stimulant abuse have largely focused on drugs that target

This research was supported by grants from the National Institute on Drug Abuse [R01DA039146 and T32DA031115] at the National Institutes of Health. The work of the Drug Design and Synthesis Section was supported by the Intramural Research Programs of the National Institute on Drug Abuse and the National Institute on Alcohol Abuse and Alcoholism at the National Institutes of Health.

https://doi.org/10.1124/jpet.117.246082. dopamine systems. Agonist-based replacement strategies (e.g., direct and indirect dopamine receptor agonists) and antagonist treatments, which aim to block the effects of stimulants at their site(s) of action (e.g., atypical DAT inhibitors and DAT receptor antagonists) have been largely unsuccessful. Thus, significant efforts have been made to develop drugs capable of modulating/dampening the effects of stimulants through nondopamine sites of actions [e.g., serotonin (5-HT) systems]. In particular, mounting evidence suggests that $5-\mathrm{HT}_{2}$ receptors play important roles in modulating dopamine neurotransmission, with $5-\mathrm{HT}_{2 \mathrm{C}}$ receptor agonists capable of decreasing the activity of dopamine systems (for review, see Howell and Cunningham, 2015). Consistent with this idea, several $5-\mathrm{HT}_{2 \mathrm{C}}$ receptor agonists have been shown to decrease the abuse-related effects of stimulants, such as cocaine, in rats and monkeys (e.g., Grottick et al., 2000; Fletcher et al., 2004; Manvich et al., 2012).

Despite promising effects in preclinical studies, agonists such as Ro 60-075 and m-CPPP are not suitable for use in humans because of a high likelihood of adverse effects (e.g., perceptual effects/hallucination, cardiovascular toxicity) linked to agonist actions at $5-\mathrm{HT}_{2 \mathrm{~A}}$, and/or $5-\mathrm{HT}_{2 \mathrm{~B}}$ receptors, respectively (Rothman and Baumann, 2009; Nichols, 2014). Lorcaserin

ABBREVIATIONS: DAT, dopamine transporter; FR, fixed ratio; 5-HT, serotonin; MDL100907, $R$-(+)-2,3-dimethoxyphenyl-1-[2-(4-piperidine)methanol]; MDPV, 3,4-methylenedioxypyrovalerone; PR, progressive ratio; SB242084, 6-chloro-5-methyl- $N$-(6-[(2-methylpyridin-3-yl)oxy]pydidin3-yl)indoline-1-carboxamide; WAY100635, N-(2-[4-(2-methoxyphenyl)-1-piperazinyl]ethyl)-N-(2-pyridyl)cyclohexanecarboxamide. 
is a 5 -HT receptor agonist that is $\sim 19$-fold selective for $5-\mathrm{HT}_{2 \mathrm{C}}$ over $5-\mathrm{HT}_{2 \mathrm{~A}}$ receptors and $\sim 105$-fold selective for 5 - $\mathrm{HT}_{2 \mathrm{C}}$ over $5-\mathrm{HT}_{2 \mathrm{~B}}$ receptors that has been shown to decrease food intake and weight gain in rats (Thomsen et al., 2008). Similar reductions in body weight were observed in a multicenter, placebo-controlled clinical trial of lorcaserin (Smith et al., 2010), and in 2012 lorcaserin was approved by the US Food and Drug Administration for the treatment of obesity in adults (Colman et al., 2012). In addition to providing a novel treatment of obesity, the approval of lorcaserin for use in humans provides a translational opportunity to evaluate the effects of a $5-\mathrm{HT}_{2 \mathrm{C}}$ receptor agonist in both preclinical and clinical settings. Indeed, when evaluated in rats and monkeys, lorcaserin has also produced dose-dependent reductions in the selfadministration of stimulants, such as cocaine and methamphetamine (Collins et al., 2016b; Gerak et al., 2016; Harvey-Lewis et al., 2016). Similarly, lorcaserin has been reported to decrease the self-administration of other drug reinforcers, including nicotine, alcohol, and oxycodone (Levin et al., 2011; Higgins et al., 2012; Rezvani et al., 2014; Neelakantan et al., 2017), suggesting that lorcaserin might have a more general effect on decreasing drug-maintained behavior. Although the capacity of a $5-\mathrm{HT}_{2 \mathrm{C}}$ receptor antagonist (SB242084) to at least partially inhibit the effects of lorcaserin on drug self-administration (Higgins et al., 2012; Harvey-Lewis et al., 2016; Neelakantan et al., 2017) suggests that these effects are mediated by the $5-\mathrm{HT}_{2 \mathrm{C}}$ receptor, the single-dose design of these experiments did not allow for the nature of the antagonist effects to be characterized (e.g., competitive and surmountable, irreversible, etc.). It is also important to note that these studies reported decreases in drug self-administration at doses of lorcaserin $(\sim 0.6-1 \mathrm{mg} / \mathrm{kg})$ that are $\sim 20$ - to 30 -fold larger than those required to induce yawning, a $5-\mathrm{HT}_{2 \mathrm{C}}$ receptor-mediated effect, and comparable to those that have been shown to produce $5-\mathrm{HT}_{2 \mathrm{~A}}$ receptormediated effects in rats (Serafine et al., 2015, 2016). Moreover, because previous studies have examined only the interactions between lorcaserin and $5-\mathrm{HT}_{2 \mathrm{C}}$ antagonists, it is currently unclear whether the actions of lorcaserin at other $5-\mathrm{HT}$ receptors (e.g., $5-\mathrm{HT}_{2 \mathrm{~A}}$ and $5-\mathrm{HT}_{1 \mathrm{~A}}$ receptors) also contribute to the capacity of lorcaserin to decrease the reinforcing effects of stimulant drugs.

Accordingly, the main goals of the current study were to 1) compare directly the effectiveness of lorcaserin to decrease the self-administration of two different stimulant drugs, cocaine and 3,4-methylenedioxypyrovalerone (MDPV), a synthetic cathinone that has cocaine-like discriminative stimulus effects (Gatch et al., 2013; Collins et al., 2016a; Gannon et al., 2016; Berquist and Baker, 2017) and is self-administered by rats (e.g., Aarde et al., 2013; Watterson et al., 2014; Schindler et al., 2016; Gannon et al., 2017a,c,d); and 2) characterize the relative contribution of $5-\mathrm{HT}_{2 \mathrm{C}}, 5-\mathrm{HT}_{2 \mathrm{~A}}$, and $5-\mathrm{HT}_{1 \mathrm{~A}}$ receptors to these effects of lorcaserin by evaluating the capacity of antagonists selective for these 5-HT receptors to shift the dose-response curve for lorcaserin to decrease the selfadministration of cocaine and MDPV.

\section{Materials and Methods}

\section{Subjects}

Six adult male Sprague-Dawley rats (275-300 g) were obtained from Harlan (Indianapolis, IN). Rats were individually housed for the duration of the study in a temperature- and light-controlled vivarium $\left(24^{\circ} \mathrm{C} ; 14 / 10\right.$-hour light/dark cycle) with free access to tap water and Purina rat chow. All procedures were in accordance with the University of
Texas Health Science Center at San Antonio Institutional Animal Care and Use Committee, and the eighth edition of the Guide for Care and Use of Laboratory Animals (National Research Council, 2011).

\section{Experimental History}

Surgery. Rats were implanted surgically with a chronic indwelling catheter in the left femoral vein under $2 \%$ isoflurane anesthesia as previously described (Gannon et al., 2017c,d), with catheters attached subcutaneously to a vascular access button between the scapulae. Rats were allotted 5-7 days to recover from surgery, during which time catheters were flushed daily with $0.5 \mathrm{ml}$ of heparinized saline (100 U/ml).

Behavioral History. All rats used in this study had previously contributed to studies reported in Gannon et al. (2017c). Briefly, rats were trained to self-administer $0.032 \mathrm{mg} / \mathrm{kg}$ per infusion MDPV during daily 90-minute sessions conducted under a FR1: timeout 5 -second schedule of reinforcement. Rats were then allowed to respond for MDPV, cocaine, or methamphetamine under a progressive ratio (PR) schedule of reinforcement where response requirement for any given infusion was determined by the equation: response requirement $=\left[5 \mathrm{e}^{\wedge}\right.$ (infusion no. $\left.\left.\times 0.2\right)\right]-5($ Richardson and Roberts, 1996), with sessions ending if the next infusion was not earned within 45 minutes. For the current studies, rats were allowed to self-administer either $0.32 \mathrm{mg} / \mathrm{kg}$ per infusion of cocaine or $0.032 \mathrm{mg} / \mathrm{kg}$ per infusion MDPV under this same PR schedule of reinforcement.

Catheter Maintenance. Catheter patency was verified by flushing $0.2 \mathrm{ml}$ of saline before and $0.5 \mathrm{ml}$ of heparinized saline $(100 \mathrm{U} / \mathrm{ml})$ after daily operant sessions. If pressure was noted during saline flushes, catheters were tested with an infusion of $3 \mathrm{mg} / \mathrm{kg}$ methohexital. Catheters were considered to have lost patency if the rat failed to exhibit rapid loss of righting reflex during the methohexital challenge. If a catheter was no longer patent, a second surgery was performed to place a catheter in the right femoral vein.

\section{Apparatus}

Experimental sessions were conducted during the light cycle in standard operant conditioning chambers (Med Associates Inc., St. Albans, VT) contained within sound-attenuating cubicles. Each chamber contained two response levers located on one wall with a set of three lights (red, yellow, and green) mounted above each lever. A house light was located at the top of the wall opposite the levers. Drug solutions were delivered by a variable speed syringe pump through Tygon tubing connected to a swivel and tether, which was secured by a counterbalanced arm.

\section{Self-Administration}

For the current study, rats were first provided access to cocaine $(0.32 \mathrm{mg} / \mathrm{kg}$ per infusion) or MDPV $(0.032 \mathrm{mg} / \mathrm{kg}$ per infusion) under a PR schedule of reinforcement. Doses of cocaine and MDPV were chosen because they maintained similar levels of responding under this PR schedule of reinforcement (i.e., functionally equivalent doses) (Gannon et al., 2017c). During baseline conditions, rats received vehicle treatments 40 and 25 minutes before the start of the selfadministration session. Once the stability criterion was met (two consecutive sessions where the number of infusions of cocaine or MDPV obtained differed by $\leq 2$ ), lorcaserin was administered 15 minutes, after vehicle (which was administered 40 minutes before the start of the session). Each dose of lorcaserin was tested for at least 2 consecutive days and until responding stabilized. After each dose of lorcaserin was tested, rats were returned to baseline conditions to ensure that responding maintained by cocaine or MDPV did not change over time. Lorcaserin doses (0.1-3.2 mg/kg, 1/2 log-unit doses) were tested in random order, and the dose of lorcaserin that decreased the number of infusions by more than $50 \%$ (relative to the baseline session immediately preceding the test) was noted for individual rats. Each rat was subsequently tested with a dose of lorcaserin 1/4 log-unit 
smaller to identify the first quarter log-unit dose of lorcaserin that reduced self-administration of cocaine or MDPV by at least $50 \%$. This dose of lorcaserin is hereafter referred to as "dose $X$." If $3.2 \mathrm{mg} / \mathrm{kg}$ lorcaserin did not reduce self-administration to at least $50 \%$ of baseline, a larger dose $(5.6 \mathrm{mg} / \mathrm{kg})$ of lorcaserin was tested. After determining the dose $X$ of lorcaserin for each subject, lorcaserin doses one-quarter and one-half log-unit less than dose $X$ (i.e., dose $X-0.25 \log$ units, and $X-0.5 \log$ units) were assessed if these doses had not previously been evaluated (see Fig. 1). To determine whether the effects of dose $X$ of lorcaserin could be surmounted, the effects of lorcaserin (dose $X$ ) were also evaluated during sessions in which responding was reinforced by a larger unit dose of cocaine $(1.78 \mathrm{mg} / \mathrm{kg}$ per infusion) or MDPV ( $0.178 \mathrm{mg} / \mathrm{kg}$ per infusion).

To determine the relative contribution of $5-\mathrm{HT}_{2 \mathrm{C}}, 5-\mathrm{HT}_{2 \mathrm{~A}}$, and 5 - $\mathrm{HT}_{1 \mathrm{~A}}$ receptors to the capacity of lorcaserin to inhibit stimulant selfadministration, rats were treated with $0.1 \mathrm{mg} / \mathrm{kg}$ of the $5-\mathrm{HT}_{2 \mathrm{C}}$ receptor antagonist SB242084, $0.1 \mathrm{mg} / \mathrm{kg}$ of the $5-\mathrm{HT}_{2 \mathrm{~A}}$ receptor antagonist MDL100907, or $0.178 \mathrm{mg} / \mathrm{kg}$ of the $5-\mathrm{HT}_{1 \mathrm{~A}}$ receptor antagonist WAY100635, 15 minutes before lorcaserin (i.e., 40 minutes before the start of the self-administration session). The doses of SB242084, MDL100907, and WAY100635 were selected based on literature reports that they effectively antagonize the hypolocomotor effects of a $5-\mathrm{HT}_{2 \mathrm{C}}$ agonist (Kennett et al., 1997), the rate decreasing effects of a $5-\mathrm{HT}_{2 \mathrm{~A}}$ receptor agonist ( $\mathrm{Li}$ et al., 2011), and the induction of fore paw treading by a $5-\mathrm{HT}_{1 \mathrm{~A}}$ receptor agonist (Serafine et al., 2015), respectively. Each antagonist was evaluated as a pretreatment to at least three lorcaserin doses (dose $X, X-0.25 \log$ units, and $X-0.5$ $\log$ units). Antagonists were tested in random order, with the doses of lorcaserin also evaluated in random order; however, all dose combinations for a given antagonist were evaluated before testing the next antagonist. If the antagonist shifted the dose-response curve of lorcaserin to the right, it was also evaluated as a pretreatment to larger doses of lorcaserin (e.g., $X+0.25 \log$ units, $X+0.5 \log$ units, etc.) until lorcaserin decreased the self-administration of cocaine $(0.32 \mathrm{mg} / \mathrm{kg}$ per infusion) or MDPV (0.032 $\mathrm{mg} / \mathrm{kg}$ per infusion) by at least $50 \%$ in all subjects. Antagonism data were collected during single session tests that were preceded by a session conducted under baseline conditions (i.e., two vehicle pretreatments).

\section{Drugs}

Lorcaserin hydrochloride was purchased from MedChem Express (Monmouth Junction, NJ). MDPV and R-(1)-2,3-dimethoxyphenyl-1-[2(4-piperidine)-methanol] (MDL100907) were synthesized in the Drug

\section{$\bigcirc \mathbf{0 . 3 2} \mathbf{~ m g} / \mathbf{k g} / \mathrm{inf}$ cocaine $\quad \square \mathbf{0 . 0 3 2} \mathbf{~ m g} / \mathbf{k g} / \mathrm{inf}$ MDPV}
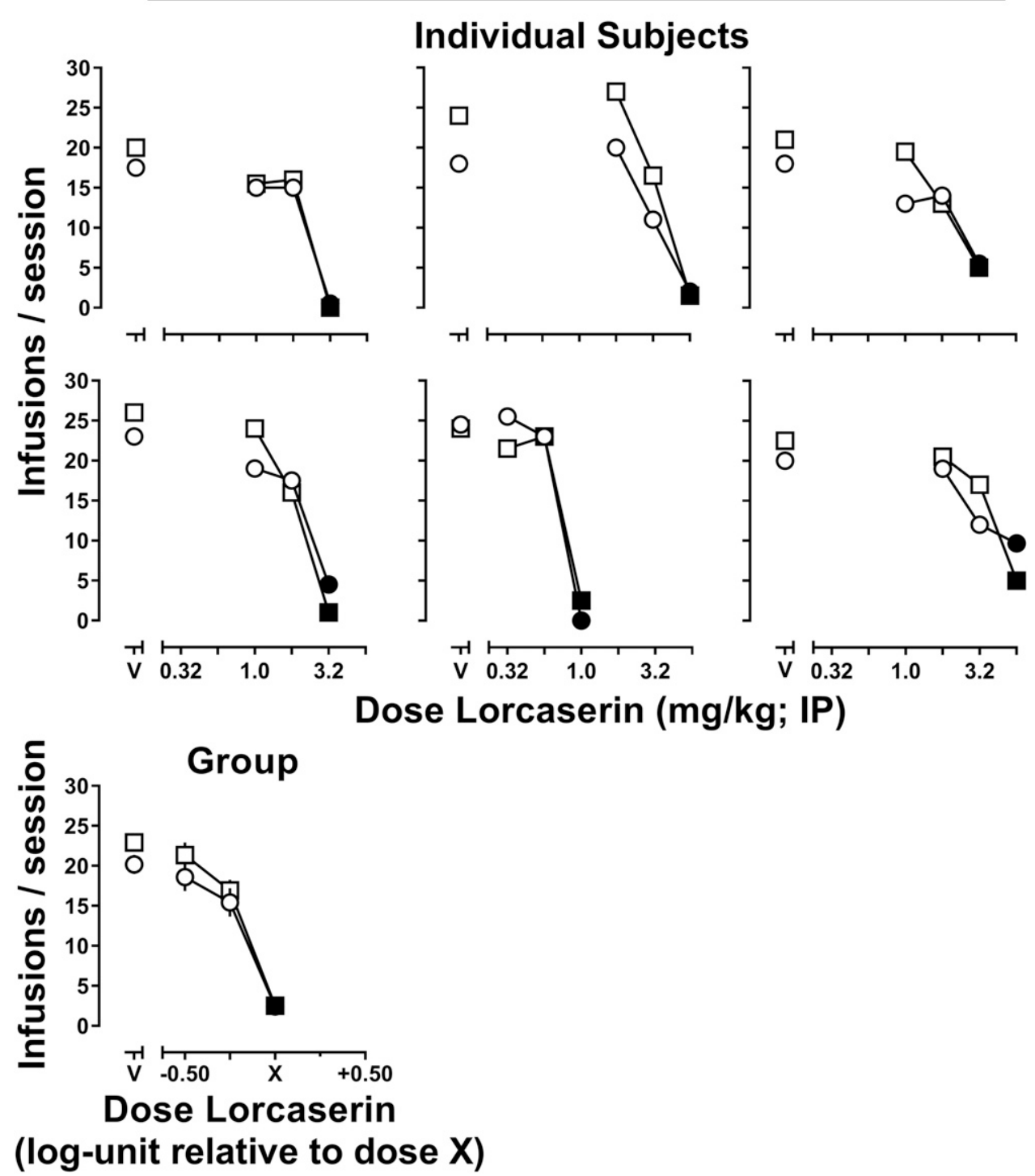

Fig. 1. Dose-dependent attenuation of self-administration of $0.32 \mathrm{mg} / \mathrm{kg}$ per inf cocaine (circles) and $0.032 \mathrm{mg} / \mathrm{kg}$ per inf MDPV (squares) by lorcaserin in individual subjects ( $n=6$, first and second rows) and at the group level (bottom row). Abscissa: $V$ represents vehicle pretreatment, whereas numbers refer to the dose of lorcaserin administered (intraperitoneally) 25 minutes before the self-administration session, expressed as milligrams per kilogram on a log scale. Ordinate: total number of infusions earned in the self-administration session. Filled symbols indicate the first dose of lorcaserin that decreased the number of infusions earned by $\geq 50 \%$ for each individual subject (i.e., dose $X$ of lorcaserin). 
Design and Synthesis Section of the National Institute on Drug Abuse by Dr. Agnieszka Sulima and/or Dr. Kenner Rice. SB242084 hydrochloride was purchased from Abcam, (Cambridge, MA). N-(2-[4-(2-methoxyphenyl)1-piperazinyl]ethyl)-N-(2-pyridyl)cyclohexane-carboxamide (WAY100635) was generously provided by Dr. Adrian Newman-Tancredi (Centre de Recherche Pierre Fabre, Castres, France). Cocaine hydrochloride was provided by the NIDA Drug Supply Program (Bethesda, MD). All drugs (except MDL100907) were dissolved in sterile 0.9\% saline; MDL100907 was dissolved in 20\% dimethylsulfoxide (DMSO; v/v). Lorcaserin, SB242084, MDL100907, WAY100635, and their respective vehicles were administered intraperitoneally in a volume of $1 \mathrm{ml} / \mathrm{kg}$ body weight. Cocaine and MDPV were administered intravenously in a volume of $0.1 \mathrm{ml} / \mathrm{kg}$ body weight.

\section{Data Analysis}

Graphical presentations of self-administration data depict the mean \pm S.E.M. number of infusions of cocaine $(0.32$ or $1.78 \mathrm{mg} / \mathrm{kg}$ per infusion) or MDPV ( 0.032 or $0.178 \mathrm{mg} / \mathrm{kg}$ per infusion) obtained for the two sessions in which the stability criteria were met. Lorcaserin dose-response data represent the mean ( \pm S.E.M.) number of infusions of cocaine or MDPV obtained as a function of the pretreatment dose of lorcaserin. Dose $X$ of lorcaserin was operationally defined as the first quarter log-unit dose of lorcaserin that reduced the number of infusions obtained to at least $50 \%$ of baseline for an individual subject. Group data were normalized using dose $X$ of lorcaserin and are therefore presented as the mean ( \pm S.E.M.) of the number of infusions of cocaine or MDPV obtained as a function of the dose lorcaserin relative to dose $X$. Repeated-measures two-way analysis of variance (lorcaserin dose $\times$ self-administered drug), followed by pairwise comparisons using the Holm-Sidak method to correct for multiple analyses, were used to determine whether the effects of lorcaserin varied as a function of the drug that was available for self-administration (i.e., cocaine or MDPV).

To determine whether the effects of lorcaserin could be surmounted by a larger unit dose of cocaine or MDPV, we compared the slope of the cocaine $(0.32-1.78 \mathrm{mg} / \mathrm{kg}$ per infusion $)$ and MDPV $(0.032-0.178 \mathrm{mg} / \mathrm{kg}$ per infusion) self-administration dose-response curves obtained under vehicle and lorcaserin (dose $X$ ) conditions. The potency of lorcaserin to decrease cocaine and MDPV self-administration by $50 \%\left(\mathrm{ID}_{50}\right)$ was obtained for individual subjects by linear regression of dose-response data spanning the $80 \%-20 \%$ effect levels normalized to baseline conditions (i.e., percentage of baseline infusions). Potency measures are reported in Table 1 and represent the mean $\mathrm{ID}_{50} \pm 95 \%$ confidence intervals. For each 5-HT antagonist, potency ratios were calculated using individual subject data (antagonist $\mathrm{ID}_{50} /$ vehicle $\mathrm{ID}_{50}$ ). Antagonists that resulted in a potency ratio for which the $95 \%$ confidence interval did not include 1 were considered to have significantly altered the effects of lorcaserin. GraphPad Prism 7 (GraphPad Software Inc., La Jolla, CA) was used to plot figures and perform statistical analyses.

\section{Results}

Figure 1 shows the number of infusions of cocaine $(0.32 \mathrm{mg} / \mathrm{kg}$ per infusion, circles) or MDPV (0.032 mg/kg per infusion, squares) earned under a PR schedule of reinforcement as a function of lorcaserin dose in individual subjects. Under vehicle pretreatment conditions, rats earned a comparable number of infusions of $0.32 \mathrm{mg} / \mathrm{kg}$ per infusion of cocaine $(20.17 \pm 1.20$ infusions $)$ and $0.032 \mathrm{mg} / \mathrm{kg}$ per infusion of MDPV (22.92 \pm 0.90 infusions), suggesting that these doses were functionally equivalent to one another. When administered as a 25-minute pretreatment, lorcaserin dose dependently decreased the self-administration of both cocaine and MDPV to a similar extent and over a similar range of doses (within subjects). Because the dose of lorcaserin required to decrease responding by $\geq 50 \%$ (filled symbols) differed among subjects $(1.0-5.6 \mathrm{mg} / \mathrm{kg})$, group data were normalized to the first quarter-log dose of lorcaserin that decreased cocaine and MDPV self-administration by $\geq 50 \%$ (i.e., dose $X$ ) (Fig. 1, bottom row). When analyzed at the group level, a two-way analysis of variance with repeated measures revealed a main effect of lorcaserin dose $[F(3,30)=109.8, P<0.0001]$ that did not differ as a function of the drug that was available for self-administration (cocaine or MDPV) $[F(1,10)=2.01, P=0.19$ ).

Figure 2 shows the effects of dose $X$ of lorcaserin when a larger dose of cocaine (1.78 $\mathrm{mg} / \mathrm{kg}$ per infusion) or MDPV $(0.178 \mathrm{mg} / \mathrm{kg}$ per infusion) was available for self-administration. Unlike the nearly complete inhibition of responding when dose $X$ of lorcaserin was administered before sessions in which rats responded for $0.32 \mathrm{mg} / \mathrm{kg}$ per infusion cocaine $(2.42 \pm 0.89$ infusions) or $0.032 \mathrm{mg} / \mathrm{kg}$ per infusion of MDPV $(2.50 \pm 0.86$ infusions), when larger doses of cocaine or MDPV were available, rats earned $12.00 \pm 3.86$ infusions of cocaine and $18.67 \pm$ 4.61 infusions of MDPV, suggesting that the effects of lorcaserin were surmounted (Fig. 2, open symbols). Indeed, the slopes of the two functions [vehicle (gray symbols) and lorcaserin (open symbols)] were not different for cocaine (right panel; $P=0.22$ ) or MDPV (left panel; $P=0.07$ ), suggesting that lorcaserin produced a rightward shift in the dose-response curves for cocaine and MDPV self-administration under a PR schedule of reinforcement.

The effects of 5-HT receptor subtype selective antagonists on lorcaserin-induced decreases in cocaine and MDPV selfadministration are depicted in Fig. 3. Pretreatment with $0.1 \mathrm{mg} / \mathrm{kg}$ of the $5-\mathrm{HT}_{2 \mathrm{C}}$ receptor antagonist SB 242084 shifted the lorcaserin dose-response curve to the right for both cocaine and MDPV self-administration (Fig. 3, top row), and the magnitude of the interaction between SB242084 and lorcaserin was comparable for both cocaine and MDPV self-administration. Pretreatment with $0.1 \mathrm{mg} / \mathrm{kg}$ of the selective $5-\mathrm{HT}_{2 \mathrm{~A}}$ receptor antagonist MDL100907 (middle row) or $0.178 \mathrm{mg} / \mathrm{kg}$ of the selective $5-\mathrm{HT}_{1 \mathrm{~A}}$ receptor antagonist WAY100635 (bottom row) did not alter the effects of lorcaserin on cocaine or MDPV self-administration. The potencies of lorcaserin in the presence of these 5-HT receptor antagonists or vehicle are reported in Table 1. As suggested by Fig. 3, pretreatment with $0.1 \mathrm{mg} / \mathrm{kg}$ of the

TABLE 1

Potency of lorcaserin to decrease cocaine and MDPV self-administration

\begin{tabular}{|c|c|c|c|c|c|}
\hline \multirow[b]{2}{*}{ Pretreatment } & \multirow[b]{2}{*}{ 5-HT Receptor Subtype } & \multicolumn{2}{|c|}{$\mathrm{ID}_{50}(95 \% \mathrm{CI})$} & \multicolumn{2}{|c|}{ Potency Ratio (95\% CI) } \\
\hline & & Cocaine & MDPV & Cocaine & MDPV \\
\hline +Vehicle & - & $2.32(1.38,3.89)$ & $2.13(1.33,3.40)$ & - & - \\
\hline +0.1 mg/kg SB242084 & $5-\mathrm{HT}_{2 \mathrm{C}}$ & $7.42 *(4.83,11.40)$ & $7.46 *(3.43,16.22)$ & $3.31 *(2.52,4.11)$ & $4.12 *(1.78,6.45)$ \\
\hline +0.1mg/kg MDL100907 & $5-\mathrm{HT}_{2 \mathrm{~A}}$ & $2.44(1.32,4.50)$ & $2.41(1.43,4.06)$ & $1.14(0.71,1.57)$ & $1.16(0.95,1.36)$ \\
\hline$+0.178 \mathrm{mg} / \mathrm{kg}$ WAY100635 & $5-\mathrm{HT}_{1 \mathrm{~A}}$ & $2.89(1.55,5.41)$ & $2.16(1.10,4.24)$ & $1.41(0.66,2.17)$ & $1.10(0.74,1.46)$ \\
\hline
\end{tabular}

*Significantly different from vehicle control conditions. 


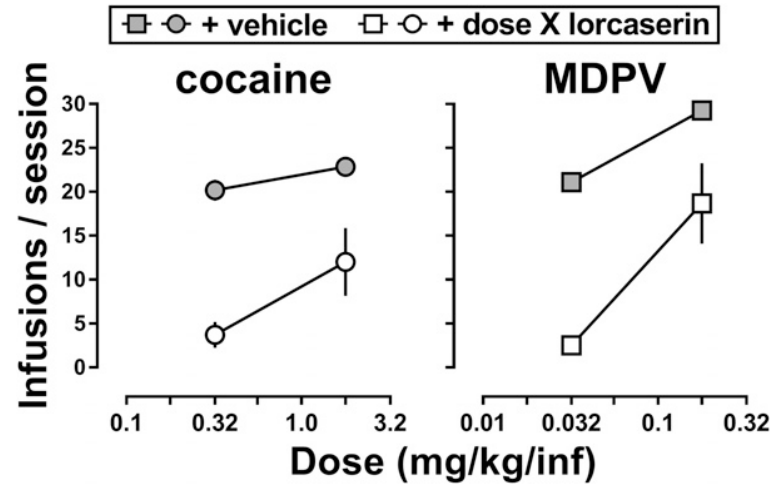

Fig. 2. The effect of dose $X$ of lorcaserin (open symbols) and vehicle (gray symbols) on cocaine (circles) and MDPV (squares) self-administration under a progressive ratio schedule of reinforcement $(n=6)$. Abscissa: numbers refer to the unit dose of cocaine (left) or MDPV (right) available for infusion, expressed as milligram per kilogram per inf on a log scale. Ordinate: total infusions \pm S.E.M. earned during the self-administration session.

$5-\mathrm{HT}_{2 \mathrm{C}}$ receptor antagonist SB242084 produced a $\sim 3$-fold reduction in the potency of lorcaserin to decrease cocaine self-administration [potency ratio of $3.31(2.52,4.11)$ ] and MDPV self-administration [potency ratio of $4.12(1.78,6.45)$, whereas pretreatment with a selective $5-\mathrm{HT}_{2 \mathrm{~A}}$ receptor antagonist (MDL100907) or a selective $5-\mathrm{HT}_{1 \mathrm{~A}}$ receptor antagonist (WAY100635) did not alter the potency of lorcaserin to decrease cocaine or MDPV self-administration (Table 1).

\section{Discussion}

Lorcaserin is a $5-\mathrm{HT}_{2 \mathrm{C}}$ receptor-preferring agonist and is approved by the Food and Drug Administration to treat obesity. Preclinical studies demonstrating that lorcaserin can decrease the ongoing self-administration of drugs with diverse mechanisms of action (e.g., nicotine, alcohol, cocaine, methamphetamine, and oxycodone) suggest that lorcaserin might also have utility as a pharmacotherapy for addiction. Although studies with $5-\mathrm{HT}_{2 \mathrm{C}}$ receptor antagonists (Higgins et al., 2012; Harvey-Lewis et al., 2016; Neelakantan et al., 2017) suggest that the capacity of lorcaserin to decrease drug self-administration is mediated by $5-\mathrm{HT}_{2 \mathrm{C}}$ receptors, the doses of lorcaserin typically required to decrease drug selfadministration are $\sim 20$ - to 30 -fold larger than those required to induce $5-\mathrm{HT}_{2 \mathrm{C}}$ receptor-mediated behavioral effects (e.g., yawning) and are comparable to those that produce $5-\mathrm{HT}_{2 \mathrm{~A}}$ receptor-mediated behavioral effects (Serafine et al., 2015, 2016) and to decrease responding for food (Higgins et al., 2012; Briggs et al., 2016; Collins et al., 2016b), raising the possibility that other 5-HT receptor subtypes are also contributing to the effectiveness of lorcaserin to decrease drug selfadministration. Accordingly, the current study sought to characterize the relative contribution of actions at $5-\mathrm{HT}_{2 \mathrm{C}}$, $5-\mathrm{HT}_{2 \mathrm{~A}}$, and $5-\mathrm{HT}_{1 \mathrm{~A}}$ receptors to the effectiveness of lorcaserin to decrease stimulant self-administration. In addition, the current study extended recent reports of the effects of lorcaserin on stimulants such as cocaine and methamphetamine (Collins et al., 2016b; Gerak et al., 2016; Harvey-Lewis et al., 2016) to MDPV, a synthetic cathinone commonly found in abused "bath salt" preparations that has been reported to be a more effective reinforcer than cocaine or methamphetamine in rats (Gannon et al., 2017c). There were three main findings: 1) lorcaserin was equipotent and equally effective at decreasing self-administration of cocaine and MDPV; 2) the capacity of lorcaserin to decrease cocaine and MDPV self-administration was surmounted by larger unit doses of cocaine and MDPV; and 3) the dose-response curves for lorcaserin to decrease selfadministration of cocaine and MDPV were shifted to the right by a $5-\mathrm{HT}_{2 \mathrm{C}}$ receptor antagonist, but not antagonists selective for $5-\mathrm{HT}_{2 \mathrm{~A}}$ or $5-\mathrm{HT}_{1 \mathrm{~A}}$ receptors. Together, these findings provide additional evidence that lorcaserin might have clinical utility for the treatment of stimulant abuse and provide strong support for the development of agonists selective for $5-\mathrm{HT}_{2 \mathrm{C}}$ receptors as pharmacotherapies for substance use disorders, more generally.

Consistent with previous studies examining the capacity of lorcaserin to decrease drug self-administration, lorcaserin dose dependently decreased self-administration of cocaine and MDPV in all subjects; however, unlike the relatively modest ( $\sim 35 \%$ reduction) effects of lorcaserin on cocaine selfadministration ( $0.25 \mathrm{mg} /$ infusion) reported by Harvey-Lewis et al. (2016), in the current studies, lorcaserin produced a nearly complete suppression of responding for both cocaine (0.32 $\mathrm{mg} / \mathrm{kg}$ per infusion) and MDPV (0.032 $\mathrm{mg} / \mathrm{kg}$ per infusion). Although these effects might seem discordant, it is important to note that the current studies evaluated a larger range of doses $(0.32-5.6 \mathrm{mg} / \mathrm{kg})$ than was previously reported (0.3-1 $\mathrm{mg} / \mathrm{kg}$ ) by Harvey-Lewis et al. (2016) to more fully characterize the effects of lorcaserin on stimulant selfadministration. Moreover, considering differences in the available dose of cocaine ( $0.25 \mathrm{mg} /$ infusion vs. $0.32 \mathrm{mg} / \mathrm{kg}$ per infusion), the steepness of the lorcaserin dose-response curve, and the fact that the $\mathrm{ID}_{50}$ values for lorcaserin to decrease responding for cocaine $(2.3 \mathrm{mg} / \mathrm{kg})$ and MDPV $(2.1 \mathrm{mg} / \mathrm{kg})$ were only slightly larger than the largest dose evaluated by Harvey-Lewis et al. (2016), the potency of lorcaserin to decrease stimulant selfadministration in the current study is more or less consistent with those reported by Harvey-Lewis and colleagues (2016).

Although factors such as the schedule of reinforcement (e.g., FR1, FR5, PR) and the drug available for self-administration (e.g., nicotine, ethanol, oxycodone, cocaine) all likely contribute to differences in the effectiveness of lorcaserin to decrease drug self-administration, the current results clearly demonstrate that lorcaserin can have profound effects on cocaine and MDPV self-administration when administered at sufficiently large doses (i.e., $~ 90 \%$ reduction in cocaine and MDPV selfadministration). Although such an effect might indicate that lorcaserin is highly effective at reducing the reinforcing effects of stimulants (e.g., cocaine and MDPV), it is also possible that these relatively large doses of lorcaserin are producing nonspecific disruptions of behavior and that these large dose effects might be mediated by receptors other than $5-\mathrm{HT}_{2 \mathrm{C}}$ receptors (e.g., $5-\mathrm{HT}_{2 \mathrm{~A}}$ or $5-\mathrm{HT}_{1 \mathrm{~A}}$ receptors).

To test whether the effects of lorcaserin (dose $X$ ) were related to changes in the reinforcing effects of cocaine and MDPV or due to a more general disruption of behavior, this dose of lorcaserin was also evaluated against larger, more reinforcing doses of cocaine $(1.78 \mathrm{mg} / \mathrm{kg}$ per infusion) and MDPV (0.178 $\mathrm{mg} / \mathrm{kg}$ per infusion). Importantly, when these larger doses of cocaine and MDPV were available for selfadministration, each of the rats increased responding, indicating that the effects of lorcaserin could be surmounted as has been reported in rhesus monkeys (Gerak et al., 2016). Although these findings suggest that the decreases in 


\section{$0.32 \mathrm{mg} / \mathrm{kg} / \mathrm{inf}$ cocaine}
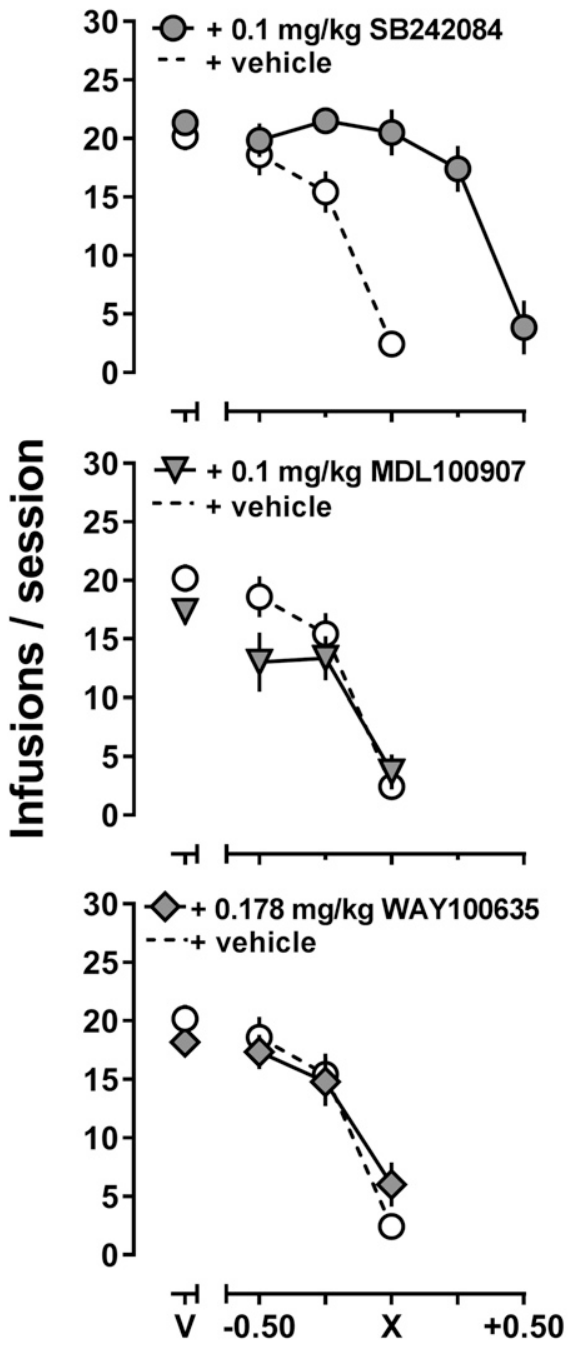

Dose Lorcaserin (log-step relative to dose $X$ )

\section{$0.032 \mathrm{mg} / \mathrm{kg} / \mathrm{inf}$ MDPV}
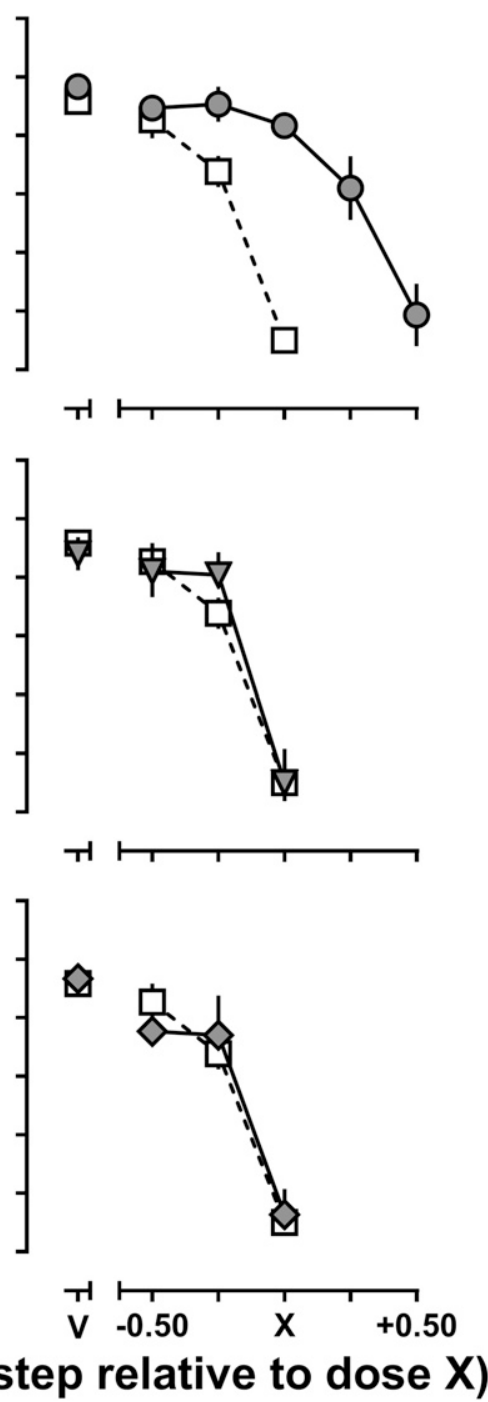

Fig. 3. The effect of selective 5-HT2C (top row), 5-HT2A (middle row), or 5-HT1A (bottom row) receptor antagonists on lorcaserin-induced decreases in $0.32 \mathrm{mg} / \mathrm{kg}$ per inf cocaine (left) and $0.032 \mathrm{mg} / \mathrm{kg}$ per inf MDPV (right) and self-administration $(n=6)$. Abscissa: $V$ represents vehicle pretreatment, log-unit dose of lorcaserin relative to the first dose of lorcaserin that decreased the number of infusions earned by $\geq 50 \%$ for each individual subject (as shown in Fig. 1). Ordinate: total infusions \pm S.E.M. earned in the self-administration session. stimulant self-administration produced by lorcaserin are related to changes in the reinforcing effectiveness of cocaine and MDPV, it is important to note that these doses of lorcaserin $(1.0-5.6 \mathrm{mg} / \mathrm{kg})$ are well within the range of doses that have reported to produce behavioral effects mediated by $5-\mathrm{HT}_{2 \mathrm{~A}}$ (head twitch) and $5-\mathrm{HT}_{1 \mathrm{~A}}$ (fore-paw treading) receptors (Serafine et al., 2015), raising the possibility that actions at $5-\mathrm{HT}_{2 \mathrm{~A}}$ and/or $5-\mathrm{HT}_{1 \mathrm{~A}}$ receptors contribute to the effectiveness of lorcaserin to decrease stimulant self-administration. Consistent with previous reports that the decreases in drug self-administration produced by lorcaserin are at least partially inhibited by the $5-\mathrm{HT}_{2 \mathrm{C}}$ receptor antagonist SB242084 (Higgins et al., 2012; Harvey-Lewis et al., 2016; Neelakantan et al., 2017), the current studies clearly demonstrated that a relatively small dose of SB242084 $(0.1 \mathrm{mg} / \mathrm{kg})$ produced a 3 - to 4-fold rightward shift in the dose-response curve for lorcaserin to decrease cocaine and MDPV self-administration. Moreover, when taken together with the fact that relatively large doses of the $5-\mathrm{HT}_{2 \mathrm{~A}}$ (MDL100907; $0.1 \mathrm{mg} / \mathrm{kg}$ ) and $5-\mathrm{HT}_{1 \mathrm{~A}}$ (WAY100635; $0.178 \mathrm{mg} / \mathrm{kg}$ ) receptor antagonists failed to alter the effects of lorcaserin, these studies provide strong evidence that the capacity of lorcaserin to decrease stimulant selfadministration is mediated by its actions at $5-\mathrm{HT}_{2 \mathrm{C}}$ receptors.

In addition to the inability of MDL100907 to shift the lorcaserin dose-response curve to the right, it is perhaps equally important to point out that pretreating animals with MDL100907 also failed to shift the lorcaserin dose-response curve to the left, as might be expected based on reports that combining a 5- $\mathrm{HT}_{2 \mathrm{~A}}$ receptor antagonist (MDL100907) with a $5-\mathrm{HT}_{2 \mathrm{C}}$ receptor agonist (WAY163909) results in a synergistic inhibition of some of the abuse-related effects of cocaine (e.g., motor activity, impulsivity, and cue reactivity) (Cunningham et al., 2013). Nevertheless, the inability of MDL100907 to alter the effects of lorcaserin does not mean that lorcaserin is devoid of agonist actions at the $5-\mathrm{HT}_{2 \mathrm{~A}}$ receptor. In addition to evidence linking the doses used in these studies to $5-\mathrm{HT}_{2 \mathrm{~A}}$ receptor-mediated effects in rats (Serafine et al., 2015, 2016), doses of lorcaserin only slightly larger than the maximum approved dose for use in humans ( $10 \mathrm{mg}$ twice daily) have been reported to increase ratings of "high" and "bad" effects and to induce perceptual effects (e.g., hallucination) and other adverse effects (e.g., nausea, headache, dizziness, euphoric 
mood, etc.) in a sample of recreational polydrug abusers (Shram et al., 2011). Although it is possible that differences in the functional selectivity of lorcaserin for $5-\mathrm{HT}_{2 \mathrm{C}}$ over $5-\mathrm{HT}_{2 \mathrm{~A}}$ receptors between rats $(\sim 3.5$-fold $)$ and humans ( 19-fold) (Thomsen et al., 2008) would result in wider margin of safety in humans (i.e., inhibition of drug-taking without also producing effects at $5-\mathrm{HT}_{2 \mathrm{~A}}$ receptors), these studies suggest that lorcaserin might have a relatively narrow therapeutic window to treat substance abuse.

In summary, these studies add to a growing literature implicating $5-\mathrm{HT}_{2 \mathrm{C}}$ receptors as important modulators of drug reinforcement (e.g., Grottick et al., 2000; Fletcher et al., 2004, 2008, 2012; Cunningham et al., 2011; Levin et al., 2011; Higgins et al., 2012; Manvich et al., 2012; Rüedi-Bettschen et al., 2015; Collins et al., 2016b; Gerak et al., 2016; HarveyLewis et al., 2016; Neelakantan et al., 2017) and provide direct evidence that lorcaserin is equipotent and effective at inhibiting the reinforcing effects of cocaine and the synthetic cathinone and "bath salts" constituent, MDPV. Moreover, these studies provide clear evidence that the capacity of lorcaserin to decrease stimulant self-administration is mediated by its actions at $5-\mathrm{HT}_{2} \mathrm{C}$, but not $5-\mathrm{HT}_{2 \mathrm{~A}}$ or $5-\mathrm{HT}_{1 \mathrm{~A}}$ receptors. Although it is difficult to predict whether lorcaserin will be effective at prolonging abstinence from stimulant use in humans, the results of the current study provide strong support for the continued development of highly selective $5-\mathrm{HT}_{2 \mathrm{C}}$ receptor agonists as pharmacotherapies for stimulant abuse.

\section{Acknowledgments}

We thank Charles P. France for generously providing the lorcaserin that was used to complete these studies.

\section{Authorship Contributions}

Participated in research design: Gannon, Collins.

Conducted experiments: Gannon.

Contributed new reagents or analytic tools: Sulima, Rice.

Performed data analysis: Gannon.

Wrote or contributed to the writing of the manuscript: Gannon, Collins.

\section{References}

Aarde SM, Huang PK, Creehan KM, Dickerson TJ, and Taffe MA (2013) The novel recreational drug 3,4-methylenedioxypyrovalerone (MDPV) is a potent psychomotor stimulant: self-administration and locomotor activity in rats. Neuropharmacology 71:130-140.

Berquist MD, II and Baker LE (2017) Characterization of the discriminative stimulus effects of 3,4-methylenedioxypyrovalerone in male Sprague-Dawley rats. Behav Pharmacol 28:394-400.

Briggs SA, Hall BJ, Wells C, Slade S, Jaskowski P, Morrison M, Rezvani AH, Rose JE, and Levin ED (2016) Dextromethorphan interactions with histaminergic and serotonergic treatments to reduce nicotine self-administration in rats. Pharmacol Biochem Behav 142:1-7.

Collins GT, Abbott M, Galindo K, Rush EL, Rice KC, and France CP (2016a) Discriminative stimulus effects of binary drug mixtures: studies with cocaine, MDPV, and caffeine. J Pharmacol Exp Ther 359:1-10.

Collins GT, Gerak LR, Javors MA, and France CP (2016b) Lorcaserin reduces the discriminative stimulus and reinforcing effects of cocaine in rhesus monkeys. $J$ Pharmacol Exp Ther 356:85-95.

Colman E, Golden J, Roberts M, Egan A, Weaver J, and Rosebraugh C (2012) The FDA's assessment of two drugs for chronic weight management. N Engl J Med 367: $1577-1579$

Cunningham KA, Anastasio NC, Fox RG, Stutz SJ, Bubar MJ, Swinford SE, Watson CS, Gilbertson SR, Rice KC, Rosenzweig-Lipson S, et al. (2013) Synergism between a serotonin 5-HT2A receptor (5-HT2AR) antagonist and 5-HT2CR agonist suggests new pharmacotherapeutics for cocaine addiction. ACS Chem Neurosci 4:110-121.

Cunningham KA, Fox RG, Anastasio NC, Bubar MJ, Stutz SJ, Moeller FG, Gilbertson SR, and Rosenzweig-Lipson S (2011) Selective serotonin 5-HT( ${ }_{2 \mathrm{C}}$ ) receptor activation suppresses the reinforcing efficacy of cocaine and sucrose but differentially affects the incentive-salience value of cocaine- vs. sucrose-associated cues. Neuropharmacology 61:513-523.

Fletcher PJ, Chintoh AF, Sinyard J, and Higgins GA (2004) Injection of the 5-HT2C receptor agonist Ro60-0175 into the ventral tegmental area reduces cocaine-induced locomotor activity and cocaine self-administration. Neuropsychopharmacology 29: $308-318$.
Fletcher PJ, Rizos Z, Noble K, Soko AD, Silenieks LB, Lê AD, and Higgins GA (2012) Effects of the 5-HT2C receptor agonist Ro60-0175 and the 5-HT2A receptor antagonist M100907 on nicotine self-administration and reinstatement. Neuropharmacology 62:2288-2298.

Fletcher PJ, Rizos Z, Sinyard J, Tampakeras M, and Higgins GA (2008) The 5-HT2C receptor agonist Ro60-0175 reduces cocaine self-administration and reinstatement induced by the stressor yohimbine, and contextual cues. Neuropsychopharmacology 33: 1402-1412.

Gannon BM, Galindo KI, Mesmin MP, Rice KC, and Collins GT (2017a) Reinforcing effects of binary mixtures of common bath salt constituents: studies with 3,4Methylenedioxypyrovalerone (MDPV), 3,4-Methylenedioxymethcathinone (Methylone), and caffeine in rats. Neuropsychopharmacology DOI: 10.1038/npp.2017.141 [published ahead of print].

Gannon BM, Galindo KI, Mesmin MP, Sulima A, Rice KC, and Collins GT (2017b) Relative reinforcing effects of second-generation synthetic cathinones: acquisition of self-administration and fixed ratio dose-response curves in rats. Neuropharmacology [published ahead of print].

Gannon BM, Galindo KI, Rice KC, and Collins GT (2017c) Individual differences in the relative reinforcing effects of 3,4-Methylenedioxypyrovalerone under fixed and progressive ratio schedules of reinforcement in rats. J Pharmacol Exp Ther 361: 181-189.

Gannon BM, Rice KC, and Collins GT (2017d) Reinforcing effects of abused 'bath salts' constituents 3,4-methylenedioxypyrovalerone and $\alpha$-pyrrolidinopentiophenone and their enantiomers. Behav Pharmacol 28:578-581.

Gannon BM, Williamson A, Suzuki M, Rice KC, and Fantegrossi WE (2016) Stereoselective effects of abused "bath salt" constituent 3,4-Methylenedioxypyrovalerone in mice: drug discrimination, locomotor activity, and thermoregulation. $J$ Pharmacol Exp Ther 356:615-623.

Gatch MB, Taylor CM, and Forster MJ (2013) Locomotor stimulant and discriminative stimulus effects of 'bath salt' cathinones. Behav Pharmacol 24:437-447.

Gerak LR, Collins GT, and France CP (2016) Effects of lorcaserin on cocaine and methamphetamine self-administration and reinstatement of responding previously maintained by cocaine in rhesus monkeys. J Pharmacol Exp Ther 359:383-391.

Grottick AJ, Fletcher PJ, and Higgins GA (2000) Studies to investigate the role of 5 -HT(2C) receptors on cocaine- and food-maintained behavior. J Pharmacol Exp Ther 295:1183-1191.

Harvey-Lewis C, Li Z, Higgins GA, and Fletcher PJ (2016) The 5-HT( ${ }_{2 \mathrm{C}}$ ) receptor agonist lorcaserin reduces cocaine self-administration, reinstatement of cocaineseeking and cocaine induced locomotor activity. Neuropharmacology 101:237-245.

Higgins GA, Silenieks LB, Rossmann A, Rizos Z, Noble K, Soko AD, and Fletcher PJ (2012) The $5-\mathrm{HT}_{2 \mathrm{C}}$ receptor agonist lorcaserin reduces nicotine self-administration, discrimination, and reinstatement: relationship to feeding behavior and impulse control. Neuropsychopharmacology 37:1177-1191.

Howell LL and Cunningham KA (2015) Serotonin 5-HT2 receptor interactions with dopamine function: implications for therapeutics in cocaine use disorder. Pharmacol Rev 67:176-197.

Kennett GA, Wood MD, Bright F, Trail B, Riley G, Holland V, Avenell KY, Stean T, Upton N, Bromidge S, et al. (1997) SB 242084, a selective and brain penetrant 5-HT2C receptor antagonist. Neuropharmacology 36:609-620.

Levin ED, Johnson JE, Slade S, Wells C, Cauley M, Petro A, and Rose JE (2011) Lorcaserin, a $5-\mathrm{HT}_{2 \mathrm{C}}$ agonist, decreases nicotine self-administration in female rats. J Pharmacol Exp Ther 338:890-896.

Li JX, Crocker C, Koek W, Rice KC, and France CP (2011) Effects of serotonin (5$\mathrm{HT})_{1 \mathrm{~A}}$ and $5-\mathrm{HT}_{2 \mathrm{~A}}$ receptor agonists on schedule-controlled responding in rats: drug combination studies. Psychopharmacology (Berl) 213:489-497.

Manvich DF, Kimmel HL, and Howell LL (2012) Effects of serotonin ${ }_{2 \mathrm{C}}$ receptor agonists on the behavioral and neurochemical effects of cocaine in squirrel monkeys. J Pharmacol Exp Ther 341:424-434.

National Research Council (2011) Guide for the Care and Use of Laboratory Animals, 8th ed, National Academies Press, Washington, DC

Neelakantan H, Holliday ED, Fox RG, Stutz SJ, Comer SD, Haney M, Anastasio NC, Moeller FG, and Cunningham KA (2017) Lorcaserin suppresses oxycodone selfadministration and relapse vulnerability in rats. ACS Chem Neurosci 8:1065-1073. Nichols DE (2004) Hallucinogens. Pharmacol Ther 101:131-181.

Rezvani AH, Cauley MC, and Levin ED (2014) Lorcaserin, a selective 5-HT( $\left.2_{2 \mathrm{C}}\right)$ receptor agonist, decreases alcohol intake in female alcohol preferring rats. Pharmacol Biochem Behav 125:8-14.

Richardson NR and Roberts DC (1996) Progressive ratio schedules in drug selfadministration studies in rats: a method to evaluate reinforcing efficacy. $J \mathrm{Neu}$ rosci Methods 66:1-11.

Ritz MC, Lamb RJ, Goldberg SR, and Kuhar MJ (1987) Cocaine receptors on dopamine transporters are related to self-administration of cocaine. Science 237: 1219-1223.

Rothman RB and Baumann MH (2009) Serotonergic drugs and valvular heart disease. Expert Opin Drug Saf 8:317-329.

Rüedi-Bettschen D, Spealman RD, and Platt DM (2015) Attenuation of cocaineinduced reinstatement of drug seeking in squirrel monkeys by direct and indirect activation of 5- $\mathrm{HT}_{2 \mathrm{C}}$ receptors. Psychopharmacology (Berl) 232:2959-2968.

Schindler CW, Thorndike EB, Goldberg SR, Lehner KR, Cozzi NV, Brandt SD, and Baumann MH (2016) Reinforcing and neurochemical effects of the "bath salts" constituents 3,4-methylenedioxypyrovalerone (MDPV) and 3,4-methylenedioxy-Nmethylcathinone (methylone) in male rats. Psychopharmacology (Berl) 233: 1981-1990.

Serafine KM, Rice KC, and France CP (2015) Directly observable behavioral effects of lorcaserin in rats. J Pharmacol Exp Ther 355:381-385.

Serafine KM, Rice KC, and France CP (2016) Characterization of the discriminative stimulus effects of lorcaserin in rats. J Exp Anal Behav 106:107-116.

Shram MJ, Schoedel KA, Bartlett C, Shazer RL, Anderson CM, and Sellers EM (2011) Evaluation of the abuse potential of lorcaserin, a serotonin 2C (5-HT2C) receptor agonist, in recreational polydrug users. Clin Pharmacol Ther 89:683-692. 
Smith SR, Weissman NJ, Anderson CM, Sanchez M, Chuang E, Stubbe S, Bays H, and Shanahan WR; Behavioral Modification and Lorcaserin for Overweight and Obesity Management (BLOOM) Study Group (2010) Multicenter, placebocontrolled trial of lorcaserin for weight management. $N$ Engl J Med 363:245-256. Thomsen WJ, Grottick AJ, Menzaghi F, Reyes-Saldana H, Espitia S, Yuskin D, Whelan K, Martin M, Morgan M, Chen W, et al. (2008) Lorcaserin, a novel selective human 5-hydroxytryptamine ${ }_{2 \mathrm{C}}$ agonist: in vitro and in vivo pharmacological characterization. J Pharmacol Exp Ther 325:577-587.

United Nations Office on Drugs and Crime (2016) World Drug Report 2016. Geneva: United Nations publication. Sales no. E.16.XI.7.
Watterson LR, Kufahl PR, Nemirovsky NE, Sewalia K, Grabenauer M, Thomas BF, Marusich JA, Wegner S, and Olive MF (2014) Potent rewarding and reinforcing effects of the synthetic cathinone 3,4-methylenedioxypyrovalerone (MDPV). Addict Biol 19:165-174.

Address correspondence to: Dr. Gregory T. Collins, University of Texas Health Science Center, Department of Pharmacology, 7703 Floyd Curl Drive, Mail Code 7764, San Antonio, TX 78229. E-mail: CollinsG@uthscsa.edu 